\title{
Recruitment And Selection Criteria Of NMB Bank PLC Branches In Mbeya Region: An Assessment Of Influence On Performance In Financial Institutions In Tanzania
}

\author{
Hadija Matimbwa \\ Ruaha Catholic University, Tanzania, hadija.matimbwa@gmail.com
}

\section{Janet Ayugi}

University of Iringa, Tanzania

\author{
Albert Ndekwa \\ Ruaha Catholic University, Iringa, Tanzania
}

\begin{abstract}
The paper assessed the contribution of recruitment and selection criteria on the performance of financial institutions in Tanzania, particularly NMB branches in Mbeya Region. The influence of education qualifications, work experience, and job related skills on the performance of NMB banks was also examined. A mixed approach adopted in a case study design was employed with questionnaires and semi structured interviews used as survey instruments; probability sampling was employed to select a representative sample from each stratum, from which a sample size of 100 bank staff that informed the study was obtained. Descriptive statistical methods where adopted to analyze data obtained from respondents, while SPSS version 20 and excel Microsoft application were used to process data. Results indicate that job related skills have a significant influence on organization performance as evidenced by a correlation coefficient of 0.666 , education levels similarly influence organisational with a correlation coefficient of 0.661 and so does employee work experience with a coefficient value of 0.487 . It is therefore recommended as per findings that banks should sufficiently apportion part of the organisational budget to employee retention and training programs to enhance their performance.
\end{abstract}

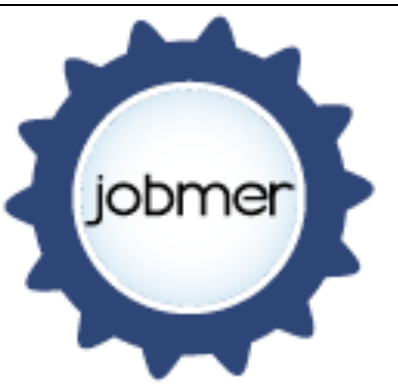

Journal of Business Management and Economic Research Vol.2, Issue.4, 2018 pp.1-10

Doi: 10.29226/TR1001.2018.26

Keywords: Recruitment, Selection, and Performance 


\section{Introduction}

\section{Background to the Problem}

In the last decade, organizations especially in Africa have been hit with the undisputable fact that the realisation of a competitive advantage significantly lies in human resources (Boxall, 2007). According to Wright and Snell (1991), human resource is the backbone and the most imperative organizational asset as it manipulates all other resources to function according to stipulated plans in an effort realize organizational goals.

It is recommended that proper staffing is critical if firms are to establish and retain a competitive advantage through strategic recruitment and selection (Wright and Snell, 1991). According to Rue and Byars (2004), recruitment is a process that involves seeking and attracting potential personnel for job vacancies and selection. On the other hand, Rue and Byars (2004), defined selection as the process of choosing from among available applicants, the individuals who are most likely to successfully execute a job. The process is dependent on proper human resource planning and recruitment. Only when an adequate pool of qualified candidates is available can the selection process function effectively. Selection is one of the most important functions of HRM because wrong employee selection enormously hampers organizational performance (Dessler, 2005).

Recruitment and Selection are major HRM functions that provide a solid foundation for HRM practices and its integration to business is critical to organizational performance (Dressler, 2005). Huselid (2005) notes that, the success of both public and private sector organisations mostly depends on the effective and efficient use of recruitment and selection processes, considering that staffs transform organizational visions and missions into reality. Thus, the objectives of any organization can only be realized through the effective co-ordination of organizational human resources.

In Tanzania, the recruitment and selection processes of most financial institutions are poorly conducted thus undermining performance (Mboma, 2006). Despite of the existing guidelines, effective recruitment, and selection in the country is challenged by recruitment on the basis of 'technical know who' as opposed to the much recommended 'technical knowhow' (Mboma, 2006). Shangali (2009) stresses that, despite the continuous improvement in adherence to the rules, regulations and procedures, governing merit based recruitment by the Appointing Authorities and employers, non-compliance on the part of some Appointing Authorities and employers particularly to rules, regulations, and procedures remains existent.

\section{Literature Review}

\section{Educational Qualifications and Organizational Performance}

The extent to which organizations perform or achieve organizational objectives is a function of staff competence (Kasika, 2015). An employer selecting from a pool of job applicants desires candidates with the right abilities and attitudes to enhance organizational performance (Ivancevich, 2004). As such, employers hire and strategically place people in various positions based on educational qualifications with the expectation of exquisite performance (Kasika, 2015). One of the most common cost-effective ways to screen for desirable abilities is by using educational qualifications as a surrogate for the measures of such abilities (Ivancevich, 2004). A positive relationship has been established between educational qualifications and employee performance (Gede and Lawanson, 2011).

The higher the educational level, the more are the effects of education on job performance skills. As such, peoples' ability to understand and use advanced technology is determined by the level 
of their education. Educated workers tend to be more responsive in receiving instructions, executing new tasks and easily adapt new technology thus, increasing their ability to innovate and improve job performance (Kasika, 2015). However, the main factors that may impede the positive effects of educational qualifications on job performance at the workplace include; quality of the work environment, organizational structure, and processes, a mismatch of employee post assignments with their qualifications and lack of an incentive system.

\section{Work experience and Organizational Performance}

Gede and Lawanson (2011), concur that work experience is imperative to the enhancement of employee performance. Giniger et al (1983) additionally found that it leads to employees' stability, desirable work attitude, mature judgment, and reduced negative work behaviours like absenteeism. Experienced employees possess internalized beliefs, values, and job expectations unique to their occupations, which results in effective socialization (Ivancevich, 2004). It is also noted that employees with experience assess their weaknesses more realistically (Hausman, Crow and Sperry, 2000). Knowledge and skills gained from previous related work experience improve employees' productivity, self-efficacy, response time to work-related challenges and hence leads to enhanced work Performance (Beyer and Hannah, 2002). Controversy however, organizations must have a rational basis for defining "relevant experience" considering that not all previous experiences are equally good predictors of performance on a given job (Ivancevich, 2004).

\section{Job Skills and Organizational Performance}

Hogan and Warrenfelz (2003) defined work skills also known as job skills as competencies and behaviours that involve direct interaction such as communicating and establishing functional relationships with others. This skill includes working as a team to complete a project or solve a problem, facilitating group interactions, leading and listening to others. According to Dessler (2005), a significant amount of research studies have examined the skills and qualities employers value most in job applicants and most studies establish that; education qualifications, work experience, communication and job skills are the most frequently identified qualities.

Gist, Stevens and Baveta (1991) found that many complex tasks in organizations require job skills which include communication, teamwork, problem solving, initiative, planning, learning and technology use, they further established that direct confrontation, and conflict resolution, can be solved by applying knowledge and skills gained from prior related work experience. Furthermore, Kersley et al (1997) highlights that most employees fail because of inadequate job skills, and the inability to communicate with colleagues. Rastogi (2000) found a link between job skills and better organizational performance, higher productivity and profitability. Moreover, relevant job skills were found to increase organizational productivity while reducing conflicts. On the contrary, insufficient job skills lead to various managerial performance dilemmas such as turnover, lack of commitment, absenteeism and sabotage (Carmeli, 2003).

\section{Methodology}

A mixed method approach in a cross sectional descriptive study design was adopted. This design facilitated the description of the role of education qualifications, work experience and job skills as they relate to bank employee performance. Probability sampling methods were used to draw a sample of 100 bank employees from the population. Data were collected using structured questionnaires and semi structured interviews. Descriptive statistics were used to analyze data collected from respondents and SPSS version 20 and excel Microsoft application 
was used to process data. Relationships between variables were established using correlation coefficient statistical calculations.

\section{Results}

\section{Demographic Information}

\section{Respondents' gender}

Since it was imperative to obtain data from both genders, both female and male NMB bank employees informed the study and gender statistics are as shown on Table 1 below.

Table 1 Gender of respondents

\begin{tabular}{|l|c|c|}
\hline & Frequency & Percent \\
\hline Male & 67 & 67.0 \\
\hline Female & 33 & 33.0 \\
\hline Total & 100 & 100.0 \\
\hline
\end{tabular}

\section{Source: field data (2017)}

As depicted on table 1 above, out of the 100 respondents who informed the study, the majority $76(76 \%)$ were male while the minority $33(33 \%)$ were female. This depicts that male employees are the majority in NMB banks in comparison to their female counterparts.

\section{Respondents' age}

Figure 1 below shows respondents' age categories particularly those who filled in questionnaires that assessed the contribution of Recruitment and Selection criteria on performance of Financial Institutions in Tanzania

Figure 1: Age of respondents

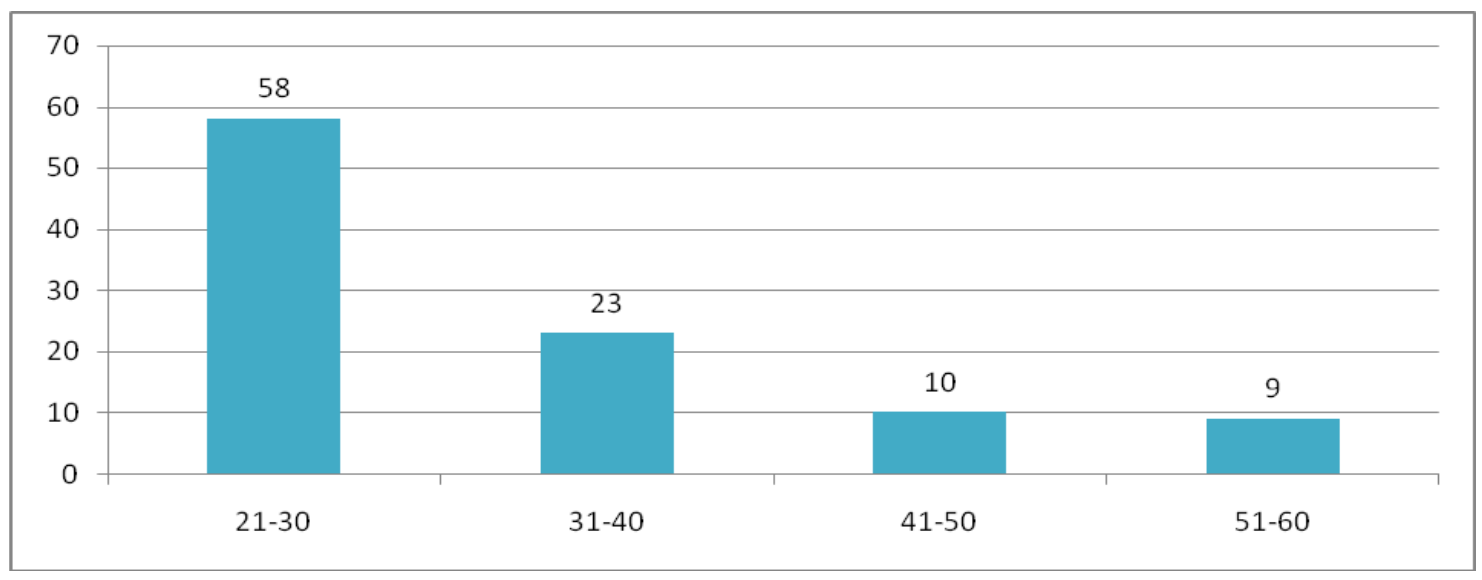

\section{Source field data (2017)}

As presented on Figure 1 above, 58\% of respondents ranged in the age category $21-40,23 \%$ were in the category $41-65,10 \%$ were aged $41-50$ while $9 \%$ were aged $51-60$. These findings imply that the majority of NMB employees are relatively young adults with minimal experience, although more likely to explore with new technology. 


\section{Respondents' education levels}

In order to determine the influence of education level on employee job performance in NMB bank, respondents' education levels where established and findings are as depicted on table 2 below:

Table 2 Respondents' education levels

\begin{tabular}{|l|c|c|}
\hline & Frequency & Percent \\
\hline Bachelor level & 65 & 65.0 \\
\hline Master level & 7 & 7.0 \\
\hline Diploma level & 14 & 14.0 \\
\hline Certificate level & 14 & 14.0 \\
\hline Total & 100 & 100.0 \\
\hline
\end{tabular}

Source: field data (2017)

As shown on table 2 above, $65 \%$ of respondents are bachelor degree holders; $14 \%$ are diploma and certificate holders, while $7 \%$ masters' degree holders. This implies that the majority of employees at NMB bank are first-degree holders, which is sufficient for effective job performance in the bank and as Ruzevicius (2006) puts it, the quality of knowledge and level of education has a significant positive impact on job performance.

\section{Respondents' work experience}

The distribution of respondents in reference to their tenure of service was also established and findings are as shown on Table3 below.

Table 3 Respondents work experience

\begin{tabular}{|l|c|c|}
\hline & Frequency & Percent \\
\hline Less than five years & 61 & 61.0 \\
\hline Between five to ten years & 19 & 19.0 \\
\hline Above ten years & 20 & 20.0 \\
\hline Total & 100 & 100.0 \\
\hline
\end{tabular}

\section{Source: field data (2017)}

As shown on table 3 above, $61 \%$ of respondents have less than 5 years of work experience while $19 \%$ have at least 10 years of work experience. Finally, 20\% have worked for NMB for over 10 years. This implies that while the majority of NMB employees have limited work experience, which may affect their work performance, the bank also has a sufficient number employees with at least 10 years of work experience and above that can be resourcefully used as mentors for their counterparts with limited experience. 


\section{The contribution of academic qualifications to NMB employee performance}

To assess the role of academic qualification on the performance of NMB employees, several questions were posed and respondents were required to state their agreement, disagreement or neutrality in reference to posed statements and findings are as indicated on Table 4 below;

Table 4: The contribution of academic qualifications to NMB employee performance

\begin{tabular}{|l|c|c|c|c|c|}
\hline & $\begin{array}{c}\text { Strongly } \\
\text { Disagree }\end{array}$ & Disagree & Neutral & Agree & $\begin{array}{c}\text { Strongly } \\
\text { Agree }\end{array}$ \\
\hline $\begin{array}{l}\text { Percentage } \\
\text { (Frq) }\end{array}$ & Per (Frq) & $\begin{array}{c}\text { Per } \\
\text { (Frq) }\end{array}$ & $\begin{array}{c}\text { Per } \\
\text { (Frq) }\end{array}$ & Per (Frq) \\
\hline $\begin{array}{l}\text { Mastery of work can only be } \\
\text { obtained from highly educated } \\
\text { employees }\end{array}$ & $29(29.0)$ & $10(10.0)$ & $14(14.0)$ & $27(27.0)$ & $20(20.0)$ \\
\hline $\begin{array}{l}\text { Possession of work skills increases } \\
\text { the quality of work }\end{array}$ & $1(1.0)$ & $3(3.0)$ & $12(12.0)$ & $52(52.0)$ & $32(32.0)$ \\
\hline $\begin{array}{l}\text { Ability to work independently } \\
\text { increases when employees have the } \\
\text { right qualification }\end{array}$ & $7(7.0)$ & $4(4.0)$ & $14(14.0)$ & $42(42.0)$ & $33(33.0)$ \\
\hline $\begin{array}{l}\text { Employees' ability to understand } \\
\text { and use advanced technology is } \\
\text { determined by the level of their } \\
\text { education }\end{array}$ & $2(2.0)$ & $4(4.0)$ & $35(35.0)$ & $47(47.0)$ & $12(12.0)$ \\
\hline $\begin{array}{l}\text { Highly educated employees are the } \\
\text { source of innovative ideas }\end{array}$ & $2(2.0)$ & $29(29.0)$ & $14(14.0)$ & $21(21.0)$ & $34(34.0)$ \\
\hline $\begin{array}{l}\text { Educated employees are the source } \\
\text { of competitive advantage }\end{array}$ & $8(8.0)$ & $4(4.0)$ & $34(34.0)$ & $34(34.0)$ & $20(20.0)$ \\
\hline $\begin{array}{l}\text { Educated workers tend to be more } \\
\text { responsive in receiving instructions } \\
\text { and perform new tasks easily }\end{array}$ & $4(4.0)$ & $18(18.0)$ & $17(17.0)$ & $32(32.0)$ & $29(29.0)$ \\
\hline $\begin{array}{l}\text { Service diversification is the } \\
\text { outcome of employees who are } \\
\text { highly educated }\end{array}$ & $20(20.0)$ & $11(11.0)$ & $14(14.0)$ & $27(27.0)$ & $28(28.0)$ \\
\hline
\end{tabular}

\section{Source: field data (2017)}

Table 4 above indicates that $47 \%$ of respondents agreed that mastery of work can only be obtained through highly educated workers, $84 \%$ of respondents concur that possession of work skills increases the quality of work; $75 \%$ agree that the ability to work independently increases when employees have appropriate qualifications. Moreover, $59 \%$ of respondents agreed with the statement "Employees ability to understand and use advanced technology is determined by the level of their education".

Furthermore, 55\% agreed that highly educated employees are the source of innovative ideas while $54 \%$ agreed that competitive advantage could only be achieved through highly educated employees. Moreover, $61 \%$ agree that educated workers tend to be more responsive in receiving instructions and performing new tasks easily. Lastly, 55\% of respondents agreed that service diversification is attributed to highly educated employees. 


\section{The contribution of work experience to NMB employee performance}

To assess the role of work experience on the performance of financial institutions, several questions were posed and respondents were required to state their agreement, disagreement or neutrality in reference to posed statements and findings are as indicated on Table 5 below;

Table 5 Role of work experience on the performance of NMB

\begin{tabular}{|c|c|c|c|c|c|}
\hline & $\begin{array}{l}\text { Strongly } \\
\text { agree }\end{array}$ & agree & Neutral & Disagree & $\begin{array}{l}\text { Strongly } \\
\text { disagree }\end{array}$ \\
\hline & $\begin{array}{l}\text { Percentage } \\
\text { (Frq) }\end{array}$ & $\begin{array}{l}\text { Per } \\
(\text { Frq })\end{array}$ & $\begin{array}{l}\text { Per } \\
\text { (Frq) }\end{array}$ & Per (Frq) & Per (Frq) \\
\hline $\begin{array}{l}\text { Experienced employees the } \\
\text { source of innovative ideas }\end{array}$ & $55(55.0)$ & $30(30.0)$ & $8(8.0)$ & $2(2.0)$ & $5(5.0)$ \\
\hline $\begin{array}{l}\text { High level of experience increases } \\
\text { the chances of providing quality } \\
\text { services }\end{array}$ & $49(49.0)$ & $36(36.0)$ & $11(11.0)$ & $1(1.0)$ & $3(3.0)$ \\
\hline $\begin{array}{l}\text { Experienced employees meet } \\
\text { deadlines }\end{array}$ & $24(24.0)$ & $18(18.0)$ & $38(38.0)$ & $14(14.0)$ & $6(6.0)$ \\
\hline $\begin{array}{l}\text { Experience promotes employee } \\
\text { confidence and allows staff to } \\
\text { work under minimum } \\
\text { supervision }\end{array}$ & $30(30.0)$ & $52(52.0)$ & $5(5.0)$ & $8(8.0)$ & $5(5.0)$ \\
\hline $\begin{array}{l}\text { The level of creativity and } \\
\text { innovation which leads to the } \\
\text { invention of new products and } \\
\text { services can be obtained through } \\
\text { experienced employees }\end{array}$ & $31(31.0)$ & $13(13.0)$ & $46(46.0)$ & $2(2.0)$ & $8(8.0)$ \\
\hline
\end{tabular}

\section{Source: field data (2017)}

As depicted on table 5 above, $85 \%$ of respondents agreed that experienced employees are the source of innovative ideas and increased chances of quality service provision, $42 \%$ agreed that experienced employees meet deadlines while $85 \%$ agreed that, work experience improves employees' confidence and allows staff to work under minimum supervision. Finally, $46 \%$ of respondents agreed that the high level of creativity and innovation, which leads to the invention of new products and services, could be achieved through experienced employees.

\section{The contribution of job skills on NMB employee performance}

This study sought to determine the influence of job skills on NMB employee performance and findings are as indicated on Table 6 below: 
Table 6: The contribution of job skills on NMB employee performance

\begin{tabular}{|l|c|c|c|c|c|}
\hline & $\begin{array}{c}\text { Strongly } \\
\text { agree }\end{array}$ & agree & Neutral & Disagree & $\begin{array}{c}\text { Strongly } \\
\text { disagree }\end{array}$ \\
\hline $\begin{array}{l}\text { Job skills enable employees to } \\
\text { solve problems }\end{array}$ & $\begin{array}{c}\text { Percentag } \\
\text { e (Frq) }\end{array}$ & $\begin{array}{c}\text { Per } \\
\text { (Frq) }\end{array}$ & $\begin{array}{c}\text { Per } \\
\text { (Frq) }\end{array}$ & Per (Frq) & Per (Frq) \\
\hline $\begin{array}{l}\text { Job skills determine employees } \\
\text { ability to perform efficiently and } \\
\text { improves their pro-activity }\end{array}$ & $38(48.0)$ & $6(6.0)$ & $0(0.0)$ & $4(4.0)$ \\
\hline $\begin{array}{l}\text { Job skills facilitate quality and } \\
\text { accurate work }\end{array}$ & $44(44.0)$ & $35(35.0)$ & $13(13.0)$ & $4(4.0)$ & $0(0.0)$ \\
\hline $\begin{array}{l}\text { Job skills increase confidence, } \\
\text { assertiveness, courage and } \\
\text { results to higher productivity }\end{array}$ & $40(40.0)$ & $19(19.0)$ & $27(27.0)$ & $14(14.0)$ & $0(0.0)$ \\
\hline $\begin{array}{l}\text { Employees with appropriate } \\
\text { skills are better team players and } \\
\text { communicators }\end{array}$ & $37(37.0)$ & $42(42.0)$ & $14(14.0)$ & $3(3.0)$ & $4(4.0)$ \\
\hline
\end{tabular}

Source: field data (2017)

As portrayed on table 6 above, $90 \%$ of respondents agree that the possession of appropriate job skills enhances employees' problem solving abilities, $65 \%$ agree that job skills determine employees' ability to perform tasks accordingly and also enhances pro-activity. Moreover, $79 \%$ agree that job skills facilitate quality and work accuracy, 59\% concur that job skills increase confidence, assertiveness, courage and higher productivity. Lastly, 79\% of respondents agree that Employees with appropriate skills are better team players and communicators.

The influence of recruitment and selection criteria on the performance of NMB branches

The researcher sought to determine the significance of the influence each recruitment and selection criteria had on NMB employee job performance therefore, the spearman correlation test was used to determine the strength of each variable.

$\gamma=\alpha+\beta_{1}$ Educationqualification,$+\beta_{2}$ Work experience $+\beta_{3}$ jobskills $+\varepsilon$ 
Table 7 Correlations output on the influence of recruitment and selection criteria on performance

\begin{tabular}{|c|c|c|c|c|c|c|}
\hline & & & PERF & EQ & WE & JS \\
\hline \multirow{12}{*}{ Spearman's rho } & \multirow{3}{*}{ PERF } & Correlation Coefficient & 1.000 & .044 & .070 & $.266^{* *}$ \\
\hline & & Sig. (2-tailed) & & .661 & .487 & .007 \\
\hline & & $\mathrm{N}$ & 100 & 100 & 100 & 100 \\
\hline & \multirow{3}{*}{ EQ } & Correlation Coefficient & $.661^{*}$ & 1.000 & .119 & $.493^{* *}$ \\
\hline & & Sig. (2-tailed) & .044 & & .240 & .000 \\
\hline & & $\mathrm{N}$ & 100 & 100 & 100 & 100 \\
\hline & \multirow{3}{*}{ WE } & Correlation Coefficient & .487 & .119 & 1.000 & $.207^{*}$ \\
\hline & & Sig. (2-tailed) & .070 & .240 & & .039 \\
\hline & & $\mathrm{N}$ & 100 & 100 & 100 & 100 \\
\hline & \multirow{3}{*}{ JS } & Correlation Coefficient & $.666^{* *}$ & $.493^{* *}$ & $.207^{*}$ & 1.000 \\
\hline & & Sig. (2-tailed) & .007 & .000 & .039 & \\
\hline & & $\mathrm{N}$ & 100 & 100 & 100 & 100 \\
\hline
\end{tabular}

**. Correlation is significant at the 0.01 level (2-tailed).

*. Correlation is significant at the 0.05 level (2-tailed).

Findings as presented on table above 7 indicate that job skills have a significant positive influence on organizational performance as evidenced by a correlation coefficient of 0.666 , followed by education levels with a correlation coefficient of 0.661 and finally employee work experience with a coefficient value of 0.487 .

\section{Conclusion}

Conclusively therefore, it can be safely put that appropriate work related skills among NMB employees in Mbeya region branches positively influence employee performance as; employee skills enhance their problem solving skills, renders employees proactive, facilitates quality and accuracy in the work executed. Appropriate employee skills also result to greater assertiveness, confidence, productivity, teamwork, and improved interpersonal communication among workers.

Work related experience has a significant positive influence on employee performance as it leads to; employee innovativeness, quality service provision, prompt execution of tasks, the ability of the employee to work with greater autonomy, and improved creativity. Finally, there is a positive significant relationship between work employees' academic qualifications and their work performance at NMB bank as academic qualification enhances; mastery and quality of work, the ability to work under minimal supervision, operation of advanced technology, responsiveness in receiving constructive feedback, thus enabling the bank to gain a competitive advantage.

Recommendations as per findings suggest that organisations especially banks like NMB Mbeya branch should device appropriate retention strategies so as to combat employee turnover and nurture vast resourceful experience among employees. Priority should also be geared towards facilitating employee professional training programs, as this will enhance their skills resulting to greater quality of services offered thus facilitating NMB in gaining a competitive edge. 


\section{REFERENCES}

Beyer, J. M., \& Hannah, D. R. (2002). Building on the past: Enacting established personal identities in a new work setting. Organization Science, 13, 636-652

Boxall, P., Purcell, J. \& Wright, P. (2007). The Oxford handbook of human resource management.New York Oxford University

Bryars, L. L., \& Rue, W. (2004).Human Resource Management (7thed.) London: McGraw-Hill Companies.

Carmeli and Tishler (2004)., The Relationship between Human Capital and Organization Performance. International Journal of Business Management

Dessler G. (2005). Human Resource Management, (10th edition). Upper Saddle River, NJ: Pearson Education Prentice Hall.

Gede, N.T. \& Lawinson, O.A. (2011).Employees' Characteristics and Job Performance of Staff of the Bayelsa State Ministry of Education

Giniger, S., Dispenzieri, A., \& Eisenberg, J. (1983). Age, experience, and performance on speed and skill jobs in an applied setting. Journal of Applied Psychology, 68, 469-475.

Gist, M. E., Stevens, C. K., \& Bavetta, A. G. (1991). Effects of self-efficacy and post-training intervention on the acquisition and maintenance of complex interpersonal skills. Personnel Psychology, 44, 837-861.

Hausman, C., Crow, G., \& Sperry, D. (2000). Portrait of the 'Ideal principal: Context and self'. NASSP Bulletin, 84, 5-14.

Huselid, M. A., Becker, B. E., \& Beatty, R. W. (2005).The workforce scorecard: Managing human capital to execute strategy. Boston: Harvard Business School Press.

Ivancevich M, J and Michael, T.,(2004).Organizational Behaviour and Management. New York McGraw.

Kasika, B.D. (2015). The Effect of Educational Qualifications on job performance: The Case of Social Security Commission in Namibia.

Kersley, Barbara and Christopher Martin (1997), Productivity Growth, Participation and Communication, Scottish Journal of Political Economy, 44(5): 485-501.

Mboma, L. (2006). ATM and Customer Satisfaction: A case of banking industry in Tanzania. The African Journal of Finance and Management, Vol. 15.

Rastogi, P. N. (2000). Sustaining enterprise competitiveness - is human capital the answer? Human Systems Management, 19: 193-203

Ruzevicius T (2006), Statistical Analysis of the different Socio- Economic Factors Affecting the Education of North Western Pakistan. Journal of Applied Quantitative Methods

Saunders, M., Lewis, P. \& Thornhill, A. (2009).Research Methods for Business People (5 ${ }^{\text {th }}$ Ed.). Harlow: Pearson Education.

Shangali, T.W. (2009).Recruitment and Selection in the Public Service: The Case of Tanzania: In Perspectives in Human Resource Governance.

Wright, P., \& Snell, S. (1991). Toward an integrative view of strategic human resource management Human Resource Management Review, 1 (4), 203-225 